\title{
POSITION OF PLURALITY OF CREDITORS AND HOLDERS OF RIGHT IN LAW AND FIQH (ISLAMIC JURISPRUDENCE)
}

\author{
Dr. Seyyed Hossein Safaei \\ Professor of Law and Political Science Faculty of Tehran University \\ hsafayii@ut.ac.ir \\ Aref Abdollahi \\ Phd Student In Private Law, Islamic Azad University, Science And Research \\ abdollahiaref1234@gmail.com
}

\begin{abstract}
Plurality of creditors and holders of right is as one of the removal of obligation examined and analyzed both in internal law and foreign law that each of creditors and holders of right can demand the debtor to full discharge of debt entirely. Plurality of creditors in reality is a complex commitment including numerous parties. In contrast, simplex and comprehensive obligations being without foreign stipulations whether its origin is contractual or out of contract, that anyway creditors - whether on individual due and or on resolvable and joint due, will be claimed independently- in the extent of portion and share of the own owner and by receiving the debt, the debtor will be cleared from obligation.
\end{abstract}

Keywords: Plurality of creditors, Holders of right, inheritance, permission

\section{INTRODUCTION}

Plurality of creditors as one of the removal of obligation was accepted by Fiqh (Islamic jurisprudence) and law. Also, it has been explained and analyzed by most of internal and foreign jurists. Some jurists have declared matters about it: they believe that plurality of creditors is used in two cases: First: in the case which single ground causes to debt among two or more debtors such as (joint liability) subject of joint account bank with right of account withdrawal by each of holders of account that is common these days, is a kind of plurality of creditors that is raised in joint liability debt lexicon. It is a manner that occurred among creditors and give right to each of creditors to claim the whole debt from obligee. Rights of all creditors do not change by joint liability debt because every creditor has just right in his own portion value. So it is clear that in joint liability debt when the creditor levy and receive the whole debt, must pay portion and share of other joint creditors. Joint liability debt is practically useless and it occurs rarely.

In Rome laws in which companies did not have corporate entity, this kind of joint liability was abundant and useful because one of the partners recover the whole debt on the behalf of others under the pretext of joint liability and pay the others share. Such joint liability has not seen out of the contracts' ambit in the current age. Thus, the other partner does not accept joint liability state in the contracts since there is a risk that the other partner can recover the whole debt (Jafari Langroodi, Mohammad Jafar, 2537, p 850).

It may be believed that each of creditors have implicitly given the power of attorney in receipt the debt to other. Therefore, the attorney must pays the collected sum to client because the main effect of joint liability among debtors as beneficiary on debt is possible in receiving the whole debt by one of them and exoneration of debtor in result of paying to every indebted, unless some claims for the personal and special reason like " incompetence and suspension and reference conditions " are not possible (Katouziyan, Naser, 2006 Spring, p 201). 
Second: it may that many reasons cause to plurality of creditors rather than debtor considered in statutes particularly in the rule of execution of civil orders and notarial writ of executions (Jafari Langroodi, Mohammad Jafar, pre, p 871).

In the case, plurality of creditors means it is feasible a person accordance to the Human Freedom principle and in the direction of enjoyment and his own vindication of civil rights, to every extent he wishes, would be engaged and debtor against others and makes a debt and right for them. Insofar as almost any laws failed to restrain debtor from his obligation (more than the actual value of his assets). Now, assume that someone attempts to set a deal with different individuals and has issued a check for one of the debtors and pledged to another or has sold a property and it did not have benefit before delivering the property, so legal situation of plurality of debtors would arise that what actions the debtor should do and what right do the creditors have rather than the debtor?

\section{First sermon: Concept of Plurality of Creditors}

In the case the creditors are plural whether the plurality had been from the first or it created through forcible or contractual transfer of property to many people, each of creditors can demand the debtors to do full payment. For example, if a number of people buys a home in common manner from a person, each of buyers can request seller the delivery of the object of demand sale.

In the above-mentioned instance, the question arises that if the seller gives the object of sale to one of the buyers and the other buyers also demand the object of sale, and the buyer who previously surrendered the estate do not allow to deliver to other buyers, do the seller may be responsible for it or not? On the other hand, in performance of obligation (warranty) about delivery of the object of sale, does the seller is obliged to deliver the object of transaction to all the partners (buyers)? And it is sufficient for exempting the debtor to fulfill one time the obligation; the seller will not be responsible for other buyers. However, regarding to the relationship among creditors, each of them is entitled to receive the debt in the amount of his portion and share. Thus, the rest of the creditors in amount of their contribution pro rata, can refer to the creditor who receive the debt, and apply for restoration of property or do not grant permission in possession of partner respect to the object of sale which has delivered to one of creditors).

In rejecting the above argument, it may be argued that the possession of each of the partners is prohibited without other partners' permission. As a result, the seller cannot deliver the object of sale to one of the partners unless the person was permitted by the other partners. In this regard, it can be declared that firstly, in such transactions, when gathering of buyers in reception of the object of sale is not provided in the contract, each of the buyers traditionally has the right of reception, lonely. Secondly, delivering the object of sale to one of the buyers, represent the title of deliver and deliver obligation would be fulfilled. It is admitted by the principle of the lack of additional being manifestation of acquittal principle. On the other word, when through delivering to one of the buyers, the title of delivery is confirmed and there is a doubt whether the seller is responsible for more or not (surrender to the all)? On the other hand, has the deliver obligation qualified to a stipulation? The principle of the lack of additional requires the answer to be negative (Amir Mohammadi, Mohammad Reza, 2014, p 55). Of course, the doctrine is not accepted in internal law unless other creditors have authorized reception of debt to receive creditor.

Some of jurists believe that none of partners can collect in common debt without permission of the other partner because the matter is possession of in other's property and, it cause damage to the other, since whatever is received from debtor is for all creditors and the astringent partner is entitled to collect his share and refer to his astringent partner (Safaei, Seyed Hosein, 1978, pp 98 and 99).

\section{Second sermon: Plurality of Creditors and Holders of Right in Stipulation Second sermon: Plurality of Creditors and Holders of Right in Statute Law}


Through investigation and search in positive laws and concerning in most of the laws, the promise (creditor) may be multiple people who are esteemed the holders of right or creditor; it does not make any difference that the creditors are as a party to an obligation with contractual origin and or with origin of obligation out of contract (external obligation). Also, it may be that multiple people begin to vindicate their rights and to receive claims sporadically mentioned in various laws and its many indications are observed respectively in civil laws, commerce, insurance, Islamic panel code.

\section{A) In civil law:}

One of the important cases in civil law to which may be referred is mortgage contract. Holder of mortgage can be multiple. The plurality of holders of right may be due to multiple causes, or single cause that is, mortgagor who is on a bail with a single origin receives a property from two partners and mortgaged them the pledge simultaneously and or it may be that hypothecator mortgages a property full due to different debts.

\section{1- Plurality of Mortgagee (pledgee)}

It is clear that the purpose of mortgage contract holding the security the debt is received and the creditor can withdraw his demand from that place. On the other words, the purpose of mortgage is that the creditor can sell the mortgage if necessary and vindicate his own claim from its price. Therefore, it is established in Article 778 of the Civil law:" if it is stipulated that the holder of a mortgage is not entitled to sell mortgage property, it is null and void. The holder of a mortgage is superior to other creditors in vindicate his claim from the mortgage and even the right is exercised on bankruptcy businessman."

If an estate is mortgaged, hypothecator is able to pledge the mortgage as a security of another debt. It means that the hypothecator has two creditors that is pledged the creditor's property due to a debt of 10 million Tomans for purchasing money of the object of sale; again, it may be that a person makes excess of the mortgage on the creditor's security for his debt of hypothecator, and the hypothecator for ensuring the creditor's claim meaning two debts with two separate and independent causes. In this case, each of holders of a mortgage toward "mortgage property" are "real and accessory right". It may be two creditors become a holder of mortgage toward a property respectively(along each other. In such a case, can it be said that the hypothecator is entitled to pledge his land (landed property) and property in pawn of two creditor compliance with the legal regulations? In this regard, some of jurists believe that if the mortgage property should be given in receipt, should all receive the mortgage in community or one of them takes possession of it on behalf of himself and on others authority? "The holders of a mortgage must determine the pledge is in possession of whom?" Article 776 of the Civil law replays (Katouziyan, Naser, 2007, p 521).

In vindication of demand of pledgees, also, everyone is in latitude of together and no one has superiority over others. The only reasonable way, then, is to divide the impute property's price proportionately among themselves after sailing. If a buyer is not found, each of them can "pro rata his own demand" take "joint tendency" from mortgage property.

It should be mentioned that if the creditors (pledgees) do not agree on the amount of every claim, and it is absolutely placed a property against several demands, all of them will be the pledges against every one of demands, mortgage or in portion of each demand only a joint part places in escrow or irrespective of the rate of demand. Eventually, half of the property is in his mortgage.

To answer the above question, two possibilities have been examined among jurists, which mortgage property toward creditors' rights in principle has dividable description or undividable, on the other hand if division of mortgage property is possible or not? Some believe that both pledgee share and partnership are appropriate. Moreover, total sum of two demands have created mortgage and the rule is that each of the whole two reasons causes a right, "pronounce sentence equally", so, should be "pronounced sentence 
equally" the pledgees' right on the credit of dividing in halves and apportionment principle and recognize each of them as a holder of a mortgage of a half of mortgage property. Some others preferred the mortgage to be divided in the ratio of demand that is, both debts should be paid through sale price of the property. If one of the two debts is more than other, then, overpayment is that more share have accrued to mortgage property in addition to in the case which mortgage means are not equal, it cannot pronounce sentence equally (the same, p 524).

However, the provisions of Article 783 of Civil law suggest that all the mortgage property is a security of each debt, and therefore will not be released until whole debt is paid.

In the assumption, two or more debts which is owed against the property regarding to relation that made in the contract, serve as a debt which "mortgage property" owned, unless it was not necessarily to create a security for independent dues in the contract.

However, the provisions of Article 783 of Civil law suggest that all the mortgage property is a security of each debt, and therefore will not be released until all debt is paid.

In the assumption, two or more debts owed against the property regarding to relation that made by contract, serve as a debt which "mortgage property" owned, unless it was not necessarily to create a security for independent dues by contract. In the other hand, when the whole mortgage is placed against sum of debts, apparently is given a security and by contract against several debts, not that any part of burden estate was as security for one of debts and single contract divided into many separate contracts which is standing to "rule of dissolution of contract into many contracts"(Bojnoordy, Mirza Hasan, Islamic Jurist's Rules, vol.6, p 28, second researcher, Comprehension Intensions, vol.1, p 287; Emami, Seyyed Hasan, p 357; Jafari Langroodi, Mohammad Jafar, p 53).

What can be analyzed from the above matters is that on the issue, the creditor can request selling all property, when all the property mortgages each debt. On the contrary, each creditor has only the right to sell his share, if only an in common share mortgaged security of each debt in proportion to its amount. In addition, if the mortgagor pays one of the creditors' debt, in the first assumption, the mortgage is not released and whole of it is other creditors' security. In the second hypothesis in ratio of his share of security, mortgage is released, meaning that mortgage property and mortgaged released and hypothecator's obligation fulfilled, if the creditor vindicates his claim from mortgage property in the amount of paid share.

According to the Article 776 of the Civil law, the single mortgage contract is divided into two contracts. Therefore, it will be still valid toward others, if herein mortgage contract to be invalidated concerning one of the creditors "for example, because of his incompetence who could not personally attend the signing". May in the mortgage contract, "creditor is one" and then in the meantime of due date "creditor become plural". In this case, the warrant of redemption of mortgage and releasing a mortgage property in the ratio of paid debt are not possible that is, it won't be redeemed any part of pledge, until all debts are paid by the debtor. For example, the mortgagee dies after the mortgage contract and before the expiration date of his claim and the inheritors take his place, in the case, creditors are plural (Jafari Langroodi- Mohammad Jafar- pre- $\mathrm{p}$ 53).

Successor (heirs) have the same rights as the legator' in lifetime. If the legator can receive part of the claim at his lifetime, he still deserves to pledge mortgage property. With his death, the inheritors will have the same right. In this regard, a jurist believes that surrogate's rights of dead person are not less than the corpse's rights. If the debtor is not entitled to redeem a part of pledgee through paying a portion of claim in the dead person's lifetime, at his death time neither does on the behalf of his successor, and in this case refers to Article 783 of the Civil Law can be invoked (Jafari Langroodi- Mohammad Jafar- pre- p 51). 


\section{2- Plurality of Beneficiary of a Surety ship}

It is possible that sometimes bailsman and principle in a contract of surety ship are one but, "beneficiary of a surety ship are several." Such assumption is possible in two states:

\section{First state}

When single bailsman has been stood surety for unique person with regard to plural beneficiary of a surety ship in different and separate contracts, and binds himself to subpoena bailsman for every one of beneficiary of a surety ship. It is so obvious that in such a case, being single some of the contract's parties does not cause interfering of contracts, and concern to beneficiary of a surety ship (multiple creditors) bailsman undertakes to summon principle in a contract of surety ship in the number of contracts located, because each contract is an independent ground for his commitment. So, fulfillment one of the commitments does not certainly result to his clearance from other obligations. It means that various obligations and debts relating to any of the creditors, in reality, will cause the bailsman to be accountable and responsible to fulfill his commitment towards creditors. On the other hand, the matter is certain and definite in which numerous means have overlapped together in creating debt and obligation and so-called principle of non-interference means.

\section{Second State}

If in a single contract, a person commits with a single contract that summon a third party to several people in the case does bailsman acquit by doing commitment toward one of the beneficiary of a surety ships, concerning to fulfill the obligation against other beneficiary of a surety ships or he is committed to subpoena bailsman for each of beneficiary of a surety ship in their number and he will be acquitted when he summoned and submit principle in a contract of surety ship to all of them? To answer the question, there is a consensus among jurisprudents. Unlike the former topic, submitting principle in a contract of surety ship by the bailsman to one of the few beneficiary of a surety ships is not considered as "clearance from obligation of bailsman against the other beneficiary of a surety ships" (Shahid Sani, Masalek al Afham, vol.4, p 250, Mohaghegh Ardebili, Majma al Faedh and Borhan, vol.9, p 327; Najafi, Javaher Al Kalam, vol. 9, p 370).

Although the contract will be dissolved at the number of beneficiary of a surety ships with numerous contracts, the bailsman's commitment fulfill in the single contract. Just like when has been committed to summon principle in a contract of surety ship for each of them individually, so that if one has warranted two debts for two people by paying the debt to one of them, his obligation is not acquitted toward another. In such a bailment, also, the situation is the same, and by summoning principle in a contract of surety ship to one, he is still liable against others. Consider that common property between two persons is on personal obligation and he is committed that delivered the property to both of them which if they settle to one of them, his obligation does not acquitted toward another person unless he is recepting to another attorney. In supposed bailment also if one of beneficiary of a surety ships is lawyer of others, summon the principle in a contract of surety ship by bailsman towards him, will be quittance bailsman against others, too.

Following the consensus of Islamic jurists, Civil law in Article 749is prescribed: "If a person goes bail an individual against many people, by submission him to one of them is not discharged against others." In this regard, most of Islamic jurists have the same words and most of Civil law expounders have the same interpretation of Article 749 of the Civil law to comply with them (Bagheri, Ahmad, 2003, p 309, Katouziyan, Naser, p 218).

The reason of bailsman's non-acquittal against other creditors and what has been stipulated in Article 749 of the Civil law has been determined because it is, in fact, several commitments of summoning undertaken bailsman by contract and must be done each of them individually and through submission principle in a contract of surety ship to one of beneficiary of a surety ships, his obligation towards others remains. Also, in a case "the debt is indivisible" like "repairing a car or drawing a canvas to the heirs of the oblige", because each of the creditors has the right to demand full commitment from principle in a 
contract of surety ship and the purpose of summon is providing equipment of possibility of demand, "bailsman commitment to the number of creditors" and summons principle in a contract of surety ship against one of them do not wave his debt against others (Katouziyan, Naser, 1997, p 472). If someone stands bail several people against joint creditor, he has fulfilled one of his obligations by summoning one of principles in a contract of surety ship and should not be considered discharged completely, because in the bail contract, it is possible that multiple debtors have owed various debts and with different origins to a single creditor. As a result, any of principles in a contract of surety is independently and distinctly undertaken against beneficiary of a surety ship in the amount of debt money, and will be nothing depending on the bail contract, but summoning principle in a contract of surety ship self and in case of violation, the bailsman will be bound to compensation for damage.

Accordingly, the beneficiary of a surety ship can compel the bailsman to summon all principles in a contract of surety ship, and citation everyone will not cause to extinction of his obligation against creditor. In plurality of beneficiary of a surety ship, if a person takes on the presence of a person against two persons, in fact, the contract is separable to two contracts although apparently a contract is concluded, for the reason, each of the two contracts should be fulfilled separately (Shahid Avval, Al Maehe Al Damsheghiyeh, p 125) ${ }^{1}$.

As it is stipulated in the Civil law, for example; by summoning bailee against one of the creditors (beneficiary of a surety ship), bailsman does not clear from obligation which it has suggested in the Article 749 and has been stipulated in the jurisprudential sources (Shahid Sani, Masalek al Afham, vol.4, p 234. Ibn Al Allameh, Izah Al Favaed, vol. 2, p 98. Abdollah Ibn Ghodameh, Almoghni, vol 5, p 100). It should be mentioned that remission of debt by one of beneficiary of a surety ship toward bailsman will not be caused to acquittal bailsman regarding to beneficiary of a surety ship which jurisprudents' beliefs is interesting to note (Allameh Helli, Thrir Al Ahkam.vol. 2, p 566).

In the civil liability discussion, also, injured parties may be multiple and they demand (compensation) damages from culprit or liable (subject or subjects of detrimental action) that it is mentioned sporadically in Civil Liability Law. In addition, According to the Article 432 of the Civil law regarding the plurality of customers, if buyers are multiple but vendor is one and appears a defect in the object of sale, right of option or exercise of the right of rescission or in other words, the right of veto/ reject should be taken together that is, it makes a single right. Furthemore, if agreement cannot be achieved, right of indemnity is fulfilled and it belongs in favor of "holder of right".

"Which the article is evidence of inseparability of right of reject in the defect object of sale that is conceivable about multiple holders of right" for reject and indemnity discrimination make damage to the vendor and its result is paying indemnity to all of holders of right (multiple buyers). And or in Article 568 of the Civil law is prescribed: "when multiple agents work together, each of them has the right of forgery as concerns his own work's amount". In the article seen that counterfeiter's obligation to pay forgery and remuneration to its stakeholders is based on the size of action taken by promisors.

In other words, if agents are two people, principle on their merit is based on their involvement in the playing the action of contract of reward's issue unless otherwise stipulated contrary that. It means, according that the agents deserve forgery and remuneration if are reached an agreement, and will act in the same way if the circumstances show that their rate of portion and share is based on the rule of dividing in halves or sharing. That is, agents' (multiple creditors and holders of right) wage and remuneration will be settled up and distributed based on the people among them.

\section{B: In Commercial law}

Subject of plurality of the commitment parties stated has been sporadically in the Commercial law. Clearly, in Articles 249, in terms of plurality of authorities or multiple debtors, consider each drawer of 
draft, endorser, and guarantor against the holder has joint and several liability or in Articles 403 of the Commercial law, which by operation of law or private contract joint and several guarantee have been recognized and joint liability is not enforceable in the cases of legislator and parties' silence, because by operation of general rules in obligations, joint liability is not presumption but must be specified that and or commitment can be considered joint liability by operation of law.

The plurality of commitment of parties from the positive aspect or, in other words the plurality of creditors that joint liability of creditors is one of its kinds can be derived or inferred, with induction in the Commercial law and the sporadic and associated laws. For example, in clause 7 of Article 223 of Commercial law mentioned that holder of bill of exchange may be numerous in which case the principle is on dividing portion and claim to each holders of right and creditor (the holder of bill of exchange) unless otherwise stipulated its contrary and or it can be attained one's share more than the other from the evidence and circumstances.

Also, in business companies especially investment companies where shareholders often are unaware of the decisions of managers and internal developments and may financial interests of many shareholders divest and join to managers' asset. By considering to the company's decision-making body that is the same combination of managers law permits shareholders to file an action by some conditions and seeking a remedy in managers' abuse. This court case is known as a Derivative Action in comparative law.

Derivative Action is a claim in which beneficiary can allege it from a legal relationship. For example, in business concerns, the company applies (Insider) in filing an action against those who have caused harm and normally are secretive of company or there is not a third parties beneficiary to raise an action (in assumption of connivance all or the majority of managers). Hence, the shareholders initiate as its beneficiary (Shareholder derivative suit. shaver holder's derivative action). In business concerns, the claim/ fight is due to the relationship between managers and shareholders that are formed because of the tensions and contradiction of interests and rights is to defend of the interests of shareholders (holders of right) through sharpening this fight.

In Iranian commercial law ,Article 276 of the Commercial law stipulates on the joint stock companies (1968): "A person or persons whose their whole stock is at least one fifth of the total share of the company will be able to raise an action against chairman or all or some of the board members and director, in case of violation or fault chairman or board of directors or director in the name and on behalf of the company and at their own expense and claim them compensation for all damages incurred to the company. Sentence will implement in favor of company and cost which paid by the initiators will be returned from sum of judgment debt If chairman or any board members or director convicted to compensation company's damages and pay proceedings fees. "If initiators convicted, paying all costs and damages lies with them. “

In addition, Article 142 and 143 of the Commercial law regarding the discussion of the joint stock companies can be of the best examples of a plurality of holders of right and creditors that through some directors abuse or violation of regulations or the company's memorandum or decisions of the plenary meeting cause making damage to partners and shareholders and third parties that sanction of breaching the rules and so on will result in claim damages and losses by the persons referred to Articles 142 and 143 and the responsibility of the offenders will be in the manner of joint.

Article 273 of the Commercial law, in addition, is stipulated that in case of issuing the final judgment on invalidity of the company or nullity of company's actions or decisions, those who are responsible for nullity will be liable severally and jointly for inflict damages on the shareholders and third parties from the annulment. Now, it is understood that the shareholders or third parties, who considered as creditors, can begin making restitution through fault or causation with institution of (legal) proceedings for their 
bills. It should be noted what was said on the derivative Action does not mean that, firstly, plaintiff for derivative Action does not necessarily have any claim or does not exist indebted person. In other words, other groups of shareholders who in the name and on behalf of the company bring a suit may not have any debt or some have personal demand and some do not have. The purpose of the litigation, is not receiving right because after taking a fund as compensation from offending managers, the money belongs to the company's assets and would not be given to the shareholders.

It should be mentioned that contrary to the derivative claim which a right directly or indirectly accrue to shareholders, in indirectly claim that has a similar mechanism to the derivate claim there is a right (claim) to the board of creditors that due to the realization of the indebted insolvency, he substitutes himself to the debtor and refers to his debtor (debtor of obligee) till after receiving the claim from third party and enriching his direct debtor's asset, vindicating the demand from that. The aim of indirect Action, in fact, is exactly attaining the right but, the derivative claim's goal is to collect the right and demand for a legal person that the result of the receipt of the right to a legal person is indirectly increase the interests and rights of shareholders and avoid further damages.

In addition, Article 154 of the Commercial law stipulated that accordance with the rules on civil liability, inspector or inspectors shall be liable to compensate inflict damages against the company and third parties with respect to offenses that are committed in the performance of their duties. The company is a set of shareholder's rights and third parties are also as holders of right and creditors from offending inspector or inspectors that can seek recovery on the basis of materialization of organs and elements of tortious liability's claim. Some jurists have also dealt with the derivative claim detailed and carefully and realize the basis for such an action from the guilt and materialization of tortious liability's claim and know redeemable the damages (Skini, Rabi'a, 1994, p. 150).

The following must be noted that under Article 277 of the Commercial law, which states that "about bringing legal action of liability against the directors of a company, provisions of articles of association and general assemblies' decision must not limit equity of the shareholders." Thus it seen that neither can prohibit the principle of the Action, nor change its terms to the detriment of shareholders, but alteration in the interest of shareholders permitted, because are compatible with the aims of law and the partners' intentions. Thus, it is also possible entitled to sue a smaller percentage of shareholders by predicting in the articles of association.

\section{A: On Insurance Law}

Insurance contracts has been defined in the Article one of Iranian insurance law ratified 1937/4/25. According to the article "Insurance is a contract whereby one party undertakes to compensate or pay a certain fund for another, in return of payment fund or funds from the other side in the event of an accident." It may, of course, be the subject of property insurance, whether original thing or usufruct or any right of property or any legal responsibility. The issue of insurance contract, so, including the entitlement of insurance property or right of property in properties insurance or legal liability in liability insurances or assured persons in insurance of individuals. It should be noted that the liability insurance is concerned to four-party: 1- "Insurer" means a person who undertakes to compensate damage in exchange of paying a premium 2- "Insured" means the party who concluded the insurance contract with the insurer, and commit to pay premiums that normally is insured person because insurance give coverage to his responsibility. 3- It is possible that insured, assures the other civil liability and accepts to pay insurance premiums which have pointed in Article 13 of civil liability law that employers as insured assure workers' civil liability against third parties to the insurer. 4- The fourth person "injured party third or third parties' "whom the legal liability of insured has been established against him.

In general rules on the rights of the insured (injured parties), It is possible that "numerous people" sustain loss in an accident (in a disasters) and or in presume "plurality of injured party", in other words, in what 
way damages and source insurance will be payable between the injured party? Are there "right of priority" in the receipt of insurance fund among them and if yes, what is the priority criteria? The kind of damage or time of incurs a loss, time of statement of claim or sentencing? or priority in receiving? Can it be said that the sum insurance must be divided "equally" or "in the ratio between injured party"?

There is no doubt that, it is not necessary to observe any hierarchy in referring of injured party (plural creditors) to insured. No injured party (a creditor) take precedence over the other and everyone can move ahead and reach to all his demand, and those who are slothful may face insolvency of the insured or insurer. The factor which reduces the discrimination is special for an assumption that insured is businessman and becomes bankrupt and his assets would divide among all his creditors (including injured party) "in the rate of their demand" (Katouziyan, Naser, Izanloo, Mohsen, 2008, p. 87).

Also, victim's withdrawal of insurer's asset will not reduce the share of other injured party. Regardless of the proceedings and issuing the verdict, insurer is obliged up to ensure ceiling and cannot invoke to limitation of the amount of insurance, if insurer has determined his commitment ceiling only by criteria of "per person" and or "per person in incident" without limiting total sum of insurance or insurance fund in every accident.

However, if the total amount of insurance or "the size of insurer liability " "per incident" is limited and the insurance sum is not enough to pay all debts of injured party, any payments on the right of the injured party will be also effective in others' contributions. So should see, how the sum insurance distributed among injured party (plural creditors) in the case.

If amount of the debt of any injured party specific, may be considered three following possibilities:

1 - It is not necessary to observe any given rule and hierarchy and every one of injured party who" act sooner than others" is owned to all his demand and may be others excluded from insurance payment.

2- Each injured party can withdraw only "in proportion to his claim" from the insurance fund.

3- The insurance fund, regardless of the amount of injured party' demand, divides "equally among them". A solution close to the first possibility is selected in English law that is, some injured parties than others are given priority and the criteria for the priority is when a verdict is given against insured. In a claim against the insured, any injured party who has obtained a verdict against the insured sooner than others has attained prior right on insurance funds (ibid., P. 88).

At first sight, the first possibility may be more consistent with legal rules, because all injured party are ordinary creditors and there is no priority and non- priority among them. So, any creditor who proceed sooner obtain his all debts and the others must endure their result of sloth (Katouziyan, Naser, 1997, No. 335, Ameli Hosseini, Seyed Mohammad javd, Meftah Al Kerameh, vol. 5, p. 114). And according the assumption, the insurer is not bankruptcy to special rules, such as division of assets in the portion of claim and prohibition of individual move of creditors is applied. On the other hand, it can be analyzed that the status of injured party against insurer who has determined a commitment limit differs from the status of ordinary creditors against the debtors. Since, the ordinary creditors can collect their own debt from the debtor's assets, everyone proceed ahead and obtain a final judgment of the court is prior to the other on receipt of the truth and demand.

It may be argued that the injured party' status of an accident approaches to plural holders of mortgage. Of course, the up aspects of two assumptions are impressive. While the issue of the injured parties' right is regarded as a debt which the holder of a mortgage can refer to the other properties of debtor to achieve his demand in the case of non-sufficient the mortgage property, detriment of injured party must be collected from arranged "capped" for restitution. 
According to the above-mentioned presumption, the number of mortgagees cannot be compared with the number of injured parties of an accident, since the first suppose is faced with an real right and in the presumption of an incident (is faced with) chose in action, that these two categories and concept are distinct together.

Given the above assumptions, it can be said that the demand of all injured party arises from an accident. The insurer is just in charge of one debt that is, commitment including plural parties. It has been accepted that insurer is in debt of the injured party jointly and severally if it is believed in the opinion that each of the injured party can collect all his demand and deprive the others, while joint liability is not supposed especially on the positive side, and does not create except with the explicit agreement of creditors. According to the principle, the injured party" demand is a commitment "continuously in the manner of sharing out" (the former No. 144) and so the site of this demand should be divided between them but, the division occurs rather on the ratio of demand not on the equality. More should be said that what was said is applicable when all injured persons are injured party of an accident.

Question: If assumed that the total sum of insurance is limited during the term of the contract and two or more incidents occur on different period in the terms of insurance contracts can preferred the injured party of the first accident over the injured party of second accident and priority is to be made for them?

Assume that the total sum of insurance is 8 million Tomans. "a" suffers damage of 7 million tomans in September and "b" two months later, incur loss equivalent of the same amount in another incident which is caused by insured. So, the question comes to mind whether the solution which is adopted in the case of loss arising from an accident is also applicable in the supposition?

To answer this question, "pro rata distribution" is not applicable in this assumption because in the previous assumption, "the basis of observing proportion" was that the obligation of the insurer is "single". In single obligation, positive parties are "plural creditors". However, on the present assumption, insurer has two different debts resulting from two different incidents and there is no continuity between these commitments and everyone is independent of the other (ibid., P. 94). Furthermore, there is no direct relation with comments on proportion criteria. Therefore, one of the two ways must be chosen: it can be believed that upon happening of the first incident, 7 million Tomans are allocated to the first injured party from the insurance site, forcibly. As a result, the second injured party and injured person are entitled to just over one million Toman of the insurance fund as what passes in the "Mortgage repeated". it can also assumed that the status of such injured persons is like other ordinary creditors and there are not prior right among them. They compete with each other and win in the competition depending on their speed. The current solution is placed in more harmony with the principle of equality of creditors (Izanloo, Mohsen, $\mathrm{p}$. 101).

However, the opinion relies on a principle in which every incident's debt is independent of another while existence of a unique insurance policy causes their affiliation, in a contract, insurer is in charge of liability of the insured to a certain subject. The only difference is that in the second presumption damage is incurred in several turns. So it must be admitted that the number of accidents does not due to plurality of debt. Because the real cause of debt is "insurance contract" and event is its recognition stipulation, as a result, in the assumption plurality of incidents, also, the rule of apportionment is the most equitable solutions (Katouziyan, Naser, Izanloo, Mohsen, the former, p. 95).

It seems that the presented theory cannot be adapted with legal rules and judicial procedures and votes taken in courts, because with institution of proceedings and completing the legal formalities and obtaining the injured party by the first injured party, Executive may be issued and the insurer company bound to implement the provisions of votes and pay compensation from the insurance policy's site in the right of judgment creditor according to legal provisions, and no property or fund shall be remained from insurance 
policy to be paid the injured party in the second incident. However, according to comments submitted, if an accident is led to a damage, since plural debts placed on duty, and basis and origin of the establishment of debt is single, the principle of demand's apportionment and degradation requires the creditors achieve something from the insurance site in the amount of their claim. In this assumption, no priority or nonpriority would cause prefer one over the other in judicial action. Of course, it is also worth noting that the injured party using the opportunity to obtain a verdict without informing the other's and in accordance to the provisions from the insurance policy's site may receive his damage and nothing was left to reach the next victim.

According to the insurance law and domestic law, such assumptions are not clearly declared by legislator. So, the same principle of priority and non- priority in the implementation and enforcement of the right should be regarded. Even if such a procedure may lead to remaining uncollectible and the imposition of loss over injured party, the fairness and justice requires that the rights of injured party to be compensated and no harm stay without compensation.

In following, another assumptions that come to mind is when in an accident a) injured party are plural, but the number of injured party is unknown and b) it is not possible to determine the amount of incurred damage of some injured parties because of their refusing to file a suit and or c) it may takes a long time to determine the compensation in a procedure, on some of injured party; for example, a injured party injures and the definitive time of treatment lasts for few years mentioned in the law of civil liability. Allocating an amount of the insurance fund to any injured person is in relationship with the determination of damages on others. So, it is difficult to determine the amount of claim of any injured party in the supposition, and requires more reflection. In America's rights, although division of the damage among injured persons having a verdict against insurer occurs "in pro rata", insurer is able to refer to sue later to persist attempt to "finish the insurance fund" against injured party who will start to file an action later (ibid. P.97).

In the assumption that accident injured party are numerous and liquidation also is not applicable, some legal authors believe that the insurer can refuse to settle up compensation to each of them by the end of the trial findings when several injured persons have filed an action. In such presumption, he cannot invoke termination of his obligation fund against plaintiffs who have achieved their verdict later than others (the same, p. 98). However, in the case that the numbers of injured party do not definite and likely other claimant and creditors join to plaintiffs for determining the right of potential injured party, the court may receive sufficient guarantee from those who collect insurance fund. "To hand over a guarantor is a perfect solution", if there is a new injured party and a new verdict is provided against liable to the accident and it appears that the division of damage has not been correctly performed among accident injured party and has come into effect an unjust performance about each of them that they are obliged to repay it for ensuring the unjust payment handing over a guarantor is a perfect solution (ibid., P. 99).

But, it can be declared that the injured person is in the position of receiving his right and damage sum payment of the injured person cannot consider kinds of unjust performance because payment has taken place by operation of law and through the court and guarantee and security the injured party has obvious mutual incompatibility and contradiction with principle of vested rights of the injured party and freedom of the parties in institution of proceedings and cannot reprimand a person who has received his right because there is no reason for equality and apportionment and the sloth injured person should be vindicate his right from another location. And because there is no explicit wording about it, the spirit of the exist provisions in the execution of the civil orders can be utilized and considered in injured parties as examples of judgment creditor or judgment creditors that court order will be considered in the order date of execution and the criterion for compensation is priority in getting the court order. 


\section{Third sermon: The Status of Plurality of Creditors and Holders of Right in Law and Fiqh (Islamic Jurisprudence)}

Here, position of plurality of creditors from the view of legal jurisprudents and scholars is investigated. Referring to the most legal books, there are beneficial and useful materials on some of the rights and claims that should be demanded by individuals or plural beneficiaries of the law or in order to vindicating that collectively, which in some of its examples, there are different views in the following topics referred to them.

\section{A: plurality of heirs in the exercise of option}

Maybe, there are plural holders of right and they do not agree on how to apply and implement the right so that some of holders of right want to independently exercise their right and some also do not have a tendency to run the right. In this respect, differences arise between the holders of rights. Now an issue arises that, do not the discrimination in the implementation of the right encounter rights of "whom against right" with an inadequate and unusual situation? Discrimination in the exercise of the right by "holder of right", cause to discrimination on the deal, which will cause inflict damage or loss to transaction party.

Option is a right for the legator. So according to the Quran he leaves a legacy it. Allameh Helli in the book of Tazkerat Alfoqaha conveys the consensus of jurists on being inheritance of option such: "All kinds of options, before we (Shiites jurists), can be inherited because the option, is the theory of preemption right and retaliation of rights and Shafei has also accepted the promise in all kinds of option, other than option of meeting place (Allameh Helli, Tazkerat Alfoqaha', vol.1, p. 536). Despite the promise of Shafi'i on option of meeting place, Ibn Zahreh has claimed consensus of Shiites on being inheritance of option of meeting place (Ibn Zahreh, Ghaniyeh Alnaze, P 221).

Ibn Idris, in addition, in his book "Saraer" has elaborated on the option of conditions and option of meeting place, that both of them do not inherit before us (Ibn Idris, Saraer, vol. 2, p. 249). It means that these two types of options cannot be transferred to the heirs and remained just for the main holder of right(deceased) during the life or in terms of case may be appointed to a third party which with dying of "option for him??" the option is also disappears and void.

Sheikh Ansari beieves about inheritance of option, as it has come in the Riyadh and used the appeared of Hadaegh: all kinds of options, inherited without difference of scholars (Ansari, Sheikh Morteza, p. 290).

Option is a fiscal right and transferable. However, in two cases of option is not transmitted through inheritance: when the option of condition is under stipulation of stewardship and is dedicated to the person in whose favor a condition is made and is not to be transferred to heirs., a perhaps a father remits a property to his son, for example, and stipulates to entitle the contract termination personally during twenty years, if he is alive. In this case due to the option has been dedicated to donor and in case of his death at this time; the right cannot be transferred to heirs. Also, the option of condition is not transferable to heirs, if it is for someone other than the transacting's parties since third party is as referee and does not fiscal right till after his death, to be transferred to his heirs.

The other tip that must be considered is that the option is an indivisible right. So, if the heirs owned many options, they can terminate the contract altogether, but breach of contract on the said of some them is not valid even toward his inheritance, because the division of option and its validity over a part of the deal will be caused to loss of the other side (Imami, Seyed Hasan, 1989, p. 533; Safai, Seyyed Hossein, 2010, p. 305; Katouziyan, Naser, 1989, p. 129).

According to Article 445 of the Civil law that stipulates: "Each of the options transferred to the heirs after the death "if the heir was sole no problem will occur and he would decide on the implementation or nonimplementation of his right like his legator and whom against right (whom against option) won't be encountered to hardness and quandary, as if the legator is to exercise the right and terminate and liquidate 
the contract. But when the heirs own many deceased options and conflict together in exercising their right, there will be many problems.

Some researchers have confirmed the possibility an assumption that a right is indivisible and belongs to the legator and after his death is given to the heirs, and each of them can exercise all of his right. For example, in the assumption that right of rescission given to heirs, some know it indivisible and belonging to each of holders of right and they conclude that any heir alone entitles to terminate the contract and in the event of a dispute among the heirs, an opinion is prior that tends to terminate (Katouziyan, Naser, exNo.907).

Some jurists believe that option may be transferred by contract. One who has option can assign his right to the other side of the transaction who the option has harm on him. For example, he can put it the price of sale and in exchange it, buys a thing from him or make peace with another property and while having right of rescission toward others transaction has rational benefit for him, the holder of option can also transfer it to a third party (Safaie, Seyed Hosein, ex, p 304). According to the theory, the nature of option has been considered as a kind of property or special right and a claim transferable to another.

Many faults would be arisen in the manner of applying the option, when the inheritors of beneficiary of an option (deceased) are many:

A: If it is believed that the manner of transmission of option also is like the other financial rights pro rata portion of inheritance of each of the heirs, issues arise that firstly, none of heirs can exercise his right lonely because right of option is an indivisible right and the right whether must be exercised or not. If among two or more of the heirs occur a dispute regarding to exercise option, it creates annoyance among several rights, and as a result, there won't be the possibility of exercise any of two rights.

B: If it is believed that the option is also divisional subject to its topic, contracting party has been placed in the position who does not want its parties' common determination because it makes the contract ripped in case of heirs disagreement, a group of heirs enforce it pro rat their own share and another group cancel it pro rata their own share. With the death of the legator each of the heirs, is the owner of right of option independently and on the other words, with the death of the legator, right of option increased in the number of heirs and each one has the complete right. The question is that how a single right becomes many rights? Because as it is never impossible an object automatically becomes multi-object without defecting, a right of option won't automatically become a few options, unless the view is that the right remains the same one right but, it granted to multiple people at a time.

Now, if an heir exercises his right of option and the other enforces the contract, how will be the contract position? The answer can be that whoever has acted sooner, others right will be oust. The answer has three basic faults: first how is it is possible someone imposes his own right and the exercise of the right caused to oust another right. Second, what status will be made if simultaneously one enforces the contract and the other terminates it? Third, by termination of one of the heirs some changes make in the other's property, and this is contrary to the principle of lack of guardianship over others (Katouziyan, Naser, ex, pp. 120, 128).

It may be asked how option of heirs is applied? There is a discrepancy about how plural heirs use a right of option. The Civil law has not discussed about it and its commentators analytically considered necessary agreement of heirs on enforcing option. Allegedly above on how to run and exercise the right of option by some of heirs and or non-exercise the right of option and signing the deal, and the lack of a special issue titled joint liability of creditors, some jurisprudents have accepted joint liability of creditors in case and scattered that knows it possible to participate in a right in the independent mode in such a way that each of the holders of right can impose all of his right independently(Tabatabaei Yazdi, Seyed Mohammad Kazem, Hashiyeh bar Makasib, 1999, p. 146, Safai, Seyed Hasan, Amir Mohammadi, Mohammad Reza, former, p. 48). 
The objection which has challenged to the theory of joint liability of holders of right is that it would cause to discrimination if one of the heirs applies the option just toward his own share or enforces the contract just toward it (his own share) and this is incompatible with the common will of the parties. But, in order to settle the problem has been told that the legislator regarded the option irresolvable and therefore, each of the heirs can only apply the option toward the whole of contract rather than his share. It should be noted that in the positive joint liability, each creditors may proceed to apply all right, but its waiver is effective only to his own share and at the present subject enforcement of the deal is as a waiver, but for applying the option of option does not need to obtain the whole consent and every one of the heirs is be able to apply the right lonely.

Concerning to the above-mentioned matters, it can be claimed that the sum of options is for the whole heirs, it means it is necessary the consensus of all heirs to enforce it. The opinion and contention is also acceptable in our law because it is a rational reason not a quoted one in a similar substantive of our law which would express in Article 445 of the Civil law: heirs inherit the option or in the other hand, "each of options transferred to the heirs after the death", but the law is silent (there is no article?) in which how do they deserve and how they can apply it. It is certain and evident that it is accurate and effective, if the heirs can unitedly exercise it whether in the manner of cancelation or signing.

The legal and lawful view should be accepted logically and rationally and from the other side justification for the view, is that it should be used of the spirit and provisions of statute (act of parliament) and deduced verdict if the law be silence (has no an article) and it is known that the purpose of the spirit of the rules is legal principles and rules which are the basis of law and also known that the Civil law has prescribed inheritance on the religiously correct and shiett Islamic law basics. So should be referred to the legal principles or Islamic credible sources or fatwas (religious edicts) in the case of law's silence, brevity and ambiguity extracted and found its sentence and because the most correct fiqh's quotes (Islamic law) or in other words well-known view of jurisprudents is that "inherited option should be applied publictotal collectively". So, this idea should be accepted in the civil law.

\section{B: Plurality of Heirs in the Exercise of Pre-emption}

Pre-emption is not defined in the Civil law. However, it is defined and interpreted as a right which is given to one of the two partners of divisible landed property to be able to own it against paying the price which buyer of the partner's portion has given to him (Katouziyan, Naser, 1991, p 214).

It is known that pre-emption right is a fiscal right and a way for acquiring and achieving the owner. Thus, the holder of right of pre-emption can forgive it or make peace with buyer against achieving a privilege. On the other hand, pre-emption right is a means for removing loss and not acquiring benefit and must be utilized in the scope of creation and philosophy of its creation.

If the partner transfers his share to the other the right will cease (because the loss's foundation disappears) and the transferee does not get it as well.

It is clear that by willfully transferring common share and portion by the pre-emption right owner, his right shots down. However, in this regard, does the right lapse and disappear, too if the transfer is in the forcible manner not voluntary? Here, it is encountered with the issue of inheritance of pre-emption right that, does the pre-emption right descend? And that how is the applying manner of right? If such a right descends and deputy of legator is plural and heirs are several people. The Civil law stipulates in Article 823: after dying the mediator the pre-emption right transmitted to his heir or heirs. And in the case that heir are plural toward the manner of application the pre-emption right and their difference in waiver and application of the pre-emption right, the question arises that Which one word and deed comes first? Article 824 of the Civil law stipulates: "when one or more of the heirs waive his, rest of the heirs cannot just exercise it toward their own right and must renounce it or apply it concerning to the whole of object of sale." 
The heirs are new owner of the pre-emption right and inherit it from the partner. The implementation of the right must be done "collectively" and in order not occur discrimination the, whole object of sale is taken possession. In other words, restrain the buyer's loss, prevents that the heirs begin to act toward their share independently.

The legal solution is in accordance with the famous opinion of Shiites jurisprudents. The opponents of the famous opinion say:" the heirs are deputy of legator, so there is an incurred effect on their fulfillment which is incurred on legator deeds and since the legator cannot apply his own right to some of the objects of sale and toward some other waiver, his heir cannot do it too (Toosi, Abi Jafar, Almabsoovt fi Al-Fiqe Imamiye, vol. 3, p. 113). On the other hand, in order to refuse division in its application, the heirs have no alternative than waving or applying all of his right.

There is a clear difference between the situation of the legator and heirs. That is, there is a right which should be applied or waived and cannot be divided and the division right is also prohibited by the legator and he did not entitle to division and discrimination the pre-emption right at his lifetime.

The legator action makes analysis the right, but the heirs' action does not break down the right because the heirs, who are also entitled to exercise their right, are qualified to apply their right in regard to the whole not as concerns their share from the pre-emption right (Safai, Seyed Hosein, Amir Mohammadi, Mohammad Reza, ex, p. 50). It exactly occurred a situation similar to the discrimination situation by the legator if some of the heirs were supposed to waive their own right in pro rata of their share of inheritance, and some other apply it pro rata their portion of inheritance (Katouziyan, Naser, 1997, p. 906).

Other justification for Article 834 of the Civil law is that, it is deemed "joint liability creditors" the right of plural heirs pro rata the pre-emptive right, mean that each of heirs is entitle to move in regard to implementation the whole of the pre-emptive right, and the his action is also valid towards the rest of the heirs. On this basis, the waiver of the pre-emption right by some of the heirs is valid only to their own right and it will not effect for the debtor by one of the creditors towards the others' right (Safai, Seyed Hosein, Amir Mohammadi, Mohammad Reza, ex, p. 51). Now it is seen that the waiver by some of creditors do not effect on the rights of other holders of right and the claim and the creditor is entitled to exercise the right to his own demand.

In joint liability of creditors, each of creditors may claim all or part of the demand if degradability, but in the operation of the pre-emption right, the holder of right, entitles to apply pro rata all.

Thus, Article 834 of the Civil law, is a legal joint liability among creditors that the legislator considers that (exercise of this right) indivisible, although it (indivisible right) is divisible, so its waiver by some heirs will not cause to divide it.

Public (Sunni) scholars as well as Shiite scholars believe in the lack of analysis in the pre-emption. "The pre-emption is not analyzable and therefore mediator has no right to obtain some part of portion and leave the rest", it is brought to the 1041's Almajaleh (Mohaghegh Damad, Seyed Mostafa, 2005, p. 140).

One of the Shiite jurisprudents believes that it is not unlikely to say on the pre-emptive right that even if the customer consents to the analysis, the mediator cannot impose his right in the discrimination manner (Sheikh Najafi, Mohammad Hassan, Javaher Alkalam, vol. 42, Tehran, Islamieh).

\section{C: Plurality of Heirs in the Permit and Deny Unauthorized Transaction}

In the unauthorized transaction which unauthorized person who carries out a transaction for him or the other without having the official agency, may dies during the concluded transaction and before declaration of the owner's permission or rejection. The question that arises is whether permission or rejection of the transaction is a part of rights that is transferable to heirs? And can the heirs be considered as a deputy or not? One of the jurists believes that theirs of the owner who are the legator deputy can accept or reject unauthorized transaction if in rejection of unauthorized transaction, the owner dies before permission or rejection of it, regarding to the legal analysis and in particular from the phrase "his deputy" 
which is stipulated in Article 247 of the Civil law because the effects of unauthorized transaction do not disappear due to the death.

Even Article 253 of this law has reserved the right of permission or rejection of the unauthorized transaction after owner's death because of the death, the landed property transferred to the heir and the owner can permit or reject the transaction toward his landed property (Imami, Seyed Hasan, 1989, p. 303). Then it is said that Article 253 of the Civil law, is about one whose landed property is assigned to another person through unauthorized transactions and dies before permission or rejection because of the death, the landed property transfer to the heir and he can reject or permit the deal toward his landed property. If unauthorized transaction is promise and has been pledged in his favor or loss and he dies before permission the unauthorized transaction becomes null and void because permission does not transfer to his heir (ibid., P. 303).

On the declaration of permission or rejection, the heirs as obligee of the unauthorized transaction may do not agree in allow or reject means what Article 253 of the Civil law announced. In following the topic which is noteworthy is that, whether permission and its application in the unauthorized transaction are divisible or not? It can be said in response that, about manner of division of permission or rejection authority, some issues should be studied. Given that according to popular opinion, the heirs entitle to permission or rejection following ownership the question arises that, how does the authority divide among the heirs? The answer is obvious if the heir is one person. Article 253 of the Civil law has not also cleared the order in the case of plurality of heirs who are negligently from the holders of right.

Perhaps in this case the solution also is useful in the discussions of inheritance, means that regarding to the portion of inheritance of heirs in the ownership of the transaction, permission or rejection divides too. For example, if a house is sold unauthorized and original owner dies before declaring permission or rejection and a he has a boy and girl since the house divides in ratio of 1 to 2 in fact, boys than girls will have the authority to allow or deny unauthorized transaction pro rata twice. In other words, according to what was said, each to heirs in that part of the property which has given to him/her, has right of permission or rejection. By accepting the view, if both of heirs allow or reject altogether the question is clear. But, as a rule the unauthorized transactions must be divided into two deals and recognize correct one and wrong the other if one of them allows the transaction and the other rejects it (ibid., P. 303).

As a result, transacting party will enter into a partnership with the rejecting party, but according to the created discrimination on the deal whether transacting party can disrupt the enforcement part or not? It can be said in response maybe with regard to being unexpected the above loss right of disrupting the transaction in the allowed amount given to transacting party. The comment is indictable about being ignorant the counterparty to the transaction toward being unauthorized the transaction, but if the person is of sound of mind, acceptance of the right of disrupting the deal will need reflection and has faults. On the contrary, it may be said that based on shares of the heritage permission or rejection does not divide, but all heirs use the right "equally" or any of the heirs authorize to allow or reject in all transaction (Tabatabaei Yazdi, Seyed Mohammad Kazem, p. 160).

On the being transferable the permission or rejection to heirs in unauthorized transaction some jurists believe that if the owner dies before permission or rejection the right which is a fiscal right and is a part of his asset transfers to the heirs and the heirs can ratify or reject the transaction (Safai, Seyed Hosein, 2003, p. 180). It seems that by the ownership of property principle the subject of unauthorized transaction, the permission or rejection is an accessory right, because as long as a right is not presumed a right rightful for the holder of right, cannot invoke to principle of deputy since a heir authorize to allow or reject who enjoy and inherit the origin property. Those who believe that the person who does not inherit a property he does not allow to transfer it. 
In addition, in confirming a view that recognizes discriminable the permission or rejection, should be said that in applying the right of holders of right, there is no consensus condition and the buyer (the original) depending on necessity of his right can use of option of sales unfulfilled in part and disappears the loss.

\section{CONCLUSION}

As explained, plurality of creditors and holders of right is as renunciation of obligation in the view of being the obligation plurality of parties which analyze and discuss in sorts of obligation including divisible or indivisible and solidarity there are signs and evidences in this regard in the Iranian legal system and with induction of rules and regulations and opinions of jurisprudents, including in rules of mortgage contract of bailment contract, that if origin mortgaged given to one of the holder of mortgage or at the bailment contract if the bailsman delivers bailee to one of the beneficiary of a surety ship whether the obligations of obligors considered have been fulfilled?

It seems that in each bailment contract of creditors (holders of mortgage) has real and accessory right rather than mortgage property and as long as the whole debt is not paid mortgage property until will still remain in pledged or obligation of bailsman still remain in bailment contract submitted by the principle in a contract of a surety ship from bailsman to one beneficiary of a surety ship which is referred to in Article 749 of the Civil law or about other rights such as inherited option and inherited pre-emption, that heir in deputy of legator is exercising his right that in the chapter of inherited option, some jurisprudents have considered to joint liability of creditors that if the heirs fail to reach an agreement on application of option , each of holders of rights can independently exercise all his right and terminates the contract or in the chapter of inheritance of pre-emption right, each of the heirs shall entitle to exercise pre-emption right toward the whole object of sale because pre-emption right is not discriminable and is applicable and enforceable to all of transaction.

Regarding permission and rejection of the unauthorized transaction, the heir of owners as plural holders of right authorize to permit or reject the deal and this right is divisible and discriminable, but the buyer to remove his loss, can use the option of sales unfulfilled in part and disturbs the contract. Generally, plurality of creditors is applicable depends on case whether in divisible or indivisible obligation or in joint commitment as renunciation of obligation and it is recommended that legislator think to an option by codifying explicit regulation especially about joint liability of creditors and holders of right and removes this legal gap, till plural creditors can refer to debtor jointly and receive and vindicate their rights and demands.

\section{REFERENCES}

Skini, Rabia, Commercial Code, Corporates, vol. 2 , the first edition, Samt Publishing 1996. Imami Seyed Hasan, Civil Rights, Vol. 1 and 2, seventh edition, published by Islamiyeh 1989.

Bagheri, Ahmad, Analytical Study of Legal Basics, Civil Liability, Draft, bailment, the first edition, Tehran University Press, 2003.

Ja'fari Langroodi, Mohammad Ja'far, Civil Rights (Mortgage and Conveyance) the first edition, Tehran, Avicenna Publishing, 1970.

Ja'fari Langroodi , Mohammad Ja'far, Civil Rights and Trade Encyclopedia, Vol. 1, the first edition , Rastad Foundation Publishing, 1978.

Shahidi, Mehdi, Effects of contracts and obligations.Vol. 3, the first edition, Majd Publications, 2003. Shahidi, Mehdi, Form Contracts and Obligations Vol. 1, the first edition, Hoghughdan Publishing, 1998. Safai, Seyed Hosein, Basic Course of Civil Rights, Vol. 2 , the first edition, General rules of Contracts, Mizan publishing ,2003.

Safai, Seyed Hosein, Rahimi Habib Allah, Civil Liability, the second edition, Samt publishing, 2011. 
Katouziyan, Naser, Izanloo Mohsen, the third volume of Civil Liability, Civil Liability Insurance, the first edition, Tehran University Press, 2008.

Katouziyan, Naser, Civil Rights, Unilateral Contract, the first edition, Yalda publishing, 1991.

Katouziyan, Naser, Civil Rights, Permission Contracts and Debt's Security, Modares publishing, the second edition, 2007.

Katouziyan, Naser, General rules of Contracts, Vol. 2 , 5 , the first edition, Sahamie Enteshar Publishing, 1989.

Katouziyan, Naser, the General Theory of Obligations, the third edition, Mizan Publishing, 1979.

Gorji, Abolghasem, Basics of Islamic Law, the first edition, Majd Publishers,2008.

Mohagheghe Damad, Seyed Mostafa, Unilateral Contract, the first edition, Islamic Sciences publishing,2008.

Safaei Syed Hosein , Articles on Civil Rights and Conformance ( Possession in common claim and initiating legal proceedings by partner in Iran's civil rights), 1996.

Safai Seyed Hosein , Amir Mohammadi Mohammad Reza, the Theory of Joint Liability in the implementation of pre-emption Right heir of Option, Legal Ideas, second year, Seventh No.

Mohammadi Abu Al Hasan, Inherited Option, Developments of Private Law (Articles Series) under the supervision of Naser Katouziyan, the second edition, Tehran, Tehran University Publishing,1992.

Izanloo Mohsen, the astonishment damage of system in liability insurance, Doctoral dissertation, Tehran University, 2004.

Amir Mohammadi, Mohammad Reza, the concept of Joint Liability and its effects with comparative study in Iran and France Law , Doctoral dissertation Tehran University,2005.

Ibn Idris, Saraer, Vol. 2. Qom.

Ibn Zahreh, Ghanie Al Nozooe, the first edition, Qom Imam Sadeq Institute.

Shahid Sani, masalek Al Afham, Vol. 4.

Tusi, Abi Ja'far, Al-Mabsut in Al-Imamiyeh Jurisprudence, Vol. 3.

MELI Hoseini Seyed Mohammad Javad, Meftah Al Kerameh in description of Jurisprudential rule, Vol. 5, Al -Albeyt Institute.

Helli Allameh, Tazkerat Al Foqaha, Vol. 1.

Mohaghegh Ardebili, Majm Al faedeh and Al-Burhan, Vol. 9.

Mohaghegh Sani, Jame Al mghased, Vol. 1, the first edition, Beirut, Ehya Institute,1411 AH

Mirza Hasan Bojnordi , rules - Al Faqih, Vol. 7 , Qom , Khayyam publishing, 1225 AH

Naeeni Mirza Mohammad Hosein, Manyh Al Taleb, Vol. 1, first edition Qom, Islamic Publication institute, 1421, AH

Sheikh Mohammad Hassan Najafi , Javaher Al Kalam, Vol. 9 , the first edition, Dar Al movarekh Al Arabi, Beirut, 1412 AH 